\title{
SAVARANKIŠKO DARBO IৃTAKA SOCIALINĖS PEDAGOGIKOS STUDIJŲ PROGRAMŲ STUDENTŲ VADYBINIŲ KOMPETENCIJŲ UGDYMUI/SI
}

\author{
Asta Mažionienè \\ Klaipédos universitetas
}

\begin{abstract}
Anotacija
Straipsnyje nagrinejjamas studentų savarankiškas darbas, kaip reikšmingas socialinių pedagogų vadybinių kompetencijų ugdymo veiksnys. Siekiant atskleisti, kaip konstruktyvistinès teorijos idejomis grindžiamas savarankiškas darbas aukštojoje mokykloje padeda studentams ugdytis vadybines kompetencijas, pasirinktas kvazieksperimentinis tyrimas. Tyrime dalyvavo 4 aukštosios mokyklos (2 universitetai ir 2 kolegijos), iš kuriu sudarytos 2 eksperimentinès (40 studentu) ir 2 kontrolinès (40 studentu) grupès. Kvazieksperimentinis tyrimas organizuotas etapais: studentų apklausa raštu (pretest) iki eksperimentinès intervencijos; eksperimentinè intervencija (test-factor), tobulinant studentu savarankišką darbą; studentų apklausa raštu (post-test) po eksperimentinès intervencijos. Palyginus rezultatų pre-test ir post-test skirtumus, ivvertintas savarankiško darbo, grindžiamo konstruktyvistinès teorijos idejjomis, poveikis socialinès pedagogikos studijų programų studentų vadybinių kompetencijų ugdymui/si. Šis tyrimas padejjo surinkti duomenis, kurie byloja, kad savarankiškas darbas, grindžiamas konstruktyvistinėmis idejjomis, padeda studentams ugdytis socialinio pedagogo darbui svarbias vadybines kompetencijas sisteminiame lygmenyje, t. y. teikiama organizuota socialinė pagalba per organizacijas ar institucijas, kurios sudaro socialinės pagalbos sistemą.

PAGRINDINIAI ŽODŽIAI: savarankiškas darbas, konstruktyvizmas, vadybinės kompetencijos, socialinè pedagogika.
\end{abstract}

\begin{abstract}
In the article individual work as a significant factor for the education of management competencies of a social care teacher has been analyzed. In order to reveal how individual work based on constructivism theories at higher school helps students to educate management competencies quasi-experimental research has been chosen. 4 higher schools ( 2 universities and 2 colleges) have participated in the research; 2 experimental (40 students) and 2 control (40 students) groups have been formed. Quasi-experimental study has been organized in separate stages: written survey of students (pre-test) before experimental intervention; experimental intervention (test-factor) by developing individual work of students; written survey of students (post-test) after experimental intervention. After the comparison of differences in results of the pre-test and the post-test, the impact of individual work based on constructivism theories on the education/self-education of management competencies of students of social pedagogy studies programmes. This research helped students to educate management competencies for work of a social care educator at systematic level, i.e. for providing social support through organizations or institutions that form the system of social support.

KEY WORDS: individual work, constructivism, management competencies, social pedagogy.
\end{abstract}

\section{Ivadas}

Vaikų socializacijos proceso valdymas pabrèžiamas pagrindiniuose socialinių pedagogų rengimą ir veiklą reglamentuojančiuose dokumentuose (Socialinio pedagogo rengimo standartas, 2008; Socialinio pedagogo kvalifikaciniai reikalavi- 
mai, 2001; Socialinio pedagogo pareiginè instrukcija, 2001): socialiniai pedagogai turi planuoti veiklą, priimti sprendimus, organizuoti, telkti, kontroliuoti, vadovauti vaikų socialinio ugdymo procesui, taigi jiems yra būtinos vadybinès kompetencijos. Tuo tarpu pastaraisiais metais atlikti tyrimai rodo, kad daugeliui socialinių pedagogų trūksta vadybinių kompetencijų (Leliūgienè, Baršauskienè, Mertinkaitytė, 2008; Indrašienè, Merfeldaitè, Petronienè, 2008; Kvieskienè ir kt., 2006; Švedaité, 2005; Buzaitytė-Kašalynienè, 2003), ypač organizuotos pagalbos, t. y. sisteminiu lygmeniu, kai socialinè pedagoginè pagalba teikiama per organizacijas ar institucijas, kurios sudaro socialinès pagalbos sistemą, o socialinis pedagogas tampa šios sistemos ir proceso vadovu. Mokslininkai (Kvieskienė, 2001; Majauskienè, Leliūgienè, 2008) pažymi, kad praktikoje labiau dominuoja socialinès pedagoginès sąveikos tarp mokyklos socialinio pedagogo ir jo adresato lygmuo. Šio straipsnio autorès (Mažionienè, Rupšienè, 2011) atlikto tyrimo duomenimis, išryškejjo socialinès pedagogikos studijų programų studentų vadybinių kompetencijų nepakankamumas tarpinstituciniame lygmenyje. Tokių kompetencijų trūkumas rodo socialinių pedagogų rengimo aukštosiose mokyklose spragas, tai reiškia, kad vadybinèms kompetencijoms skiriama nepakankamai dėmesio. Praktinis socialinių pedagogu vadybinių kompetencijų poreikis skatina ieškoti rezervų studijų programose, kad šios kompetencijos būtų efektyviau išugdomos.

Kaip veiksmingai ugdyti studijuojančiujų pagal socialinès pedagogikos studijų programas vadybines kompetencijas - iki šiol dar moksliškai nespręstas klausimas. Iš valdymo teorijos (Stankevičienè, Lobanova, 2006; Stoner, Freeman, Gilbert, 2005; Želvys, 2003; 2001; Zakarevičius, 2002; Seilius, 1998) yra žinoma, kad vadybinès kompetencijos apima žinias, gebejimus ir nuostatas, reikalingas valdymo funkcijoms atlikti: planavimo, organizavimo, vadovavimo ir kontrolès. Vis daugeja irodymų, kad kompetencijų studijų procese galima igyti per efektyvų savarankišką studentų darbą (Šiaučiukènienè, Visockienė, Talijūnienė, 2006; Broad, 2006; Nieto, Dimitriadou, Davy, 2008; Pečiūrienė, Radlinskaitė, Žvinakevičienè, 2010; Tandzegolskienè, Pileckaite, 2010). Remiantis šio darbo autorès (Rupšienè, Mažioniené, 2011b) atlikto tyrimo duomenimis, taip galima igyti ir vadybinių kompetencijų.

Savarankiškas darbas aukštojoje mokykloje suprantamas kaip mokymo(si) sistema, integrali tarpusavyje susijusių elementu sąveika, sudaranti sąlygas studentams ugdytis būtinas kompetencijas (Rupšienè, Mažionienè, 2011; Pečiūrienè, Radlinskaitė, Žvinakevičienė, 2010; Tandzegolskienė, Pileckaitè, 2010; Le Boterf, 2009; Nieto, Dimitriadou, Davy, 2008; Broad, 2006; Šiaučiukèniené, Visockienè, Talijūnienè, 2006; Hendry, Hyde, Davy, 2005; Dillon, Greene, Mansell, 2005; Brunevičiūtè, Gudaitytè, Starkutè, Šarkauskienè, 2003). 
Šiuolaikinio aukštojo mokslo studijose savarankiškas darbas grindžiamas naujaja mokymosi paradigma ir konstruktyvistine teorija, kuri teigia, kad mokymasis yra procesas, kuriame besimokantysis aktyviai dalyvaudamas, taikydamas žinias praktinejje veikloje, vertindamas jų nauda, igytos patirties pagrindu tobulina kompetencijas. Konstruktyvistinės teorijos požiūriu, mokymasis yra žinių konstravimas per patirti, skatinant aktyvų mokymąsi, mokymąsi „darant“. Konstruktyvizmo požiūriu, žinios ir gebejjimai konstruojami individams socialiai dalyvaujant veikloje, sprendžiant problemas ar atliekant užduotis (Pečiūrienė ir kt., 2010; Šliogerienè ir kt., 2009; Valuckienė, 2009; Šiaučiukènienė ir kt., 2006; Brunevičiūtė ir kt., 2003).

Diegiant šiuolaikinę mokymosi paradigmą būtina, kad studentų savarankiškas darbas aukštojoje mokykloje sudarytų pagrindą studentų kompetencijų ugdymui (Brunevičiūtè, Gudaitytè, Starkutè, Šarkauskienė, 2003; Pečiūrienė, Radlinskaitè, Žvinakevičienè, 2010; Nieto, Dimitriadou, Davy, 2008; Dačiulytė, 2003). Todèl yra pagrindo tyrinèti konstruktyvistinėmis idejjomis grindžiamą studentų savarankišką darbą kaip reikšmingą vadybinių kompetencijų ugdymo veiksni.

Tyrimo objektu pasirinkus konstruktyvistinèmis idejjomis grindžiamą studentų savarankišką darbą, šiame straipsnyje iškeltas tikslas - atskleisti konstruktyvistinėmis idèjomis grindžiamo savarankiško darbo įtaką socialinès pedagogikos studijų programų studentų vadybinių kompetencijų ugdymui/si.

\section{Tyrimo metodologija}

Siekiant atskleisti, kaip konstruktyvistinès teorijos idejomis grindžiamas savarankiškas darbas aukštojoje mokykloje padeda socialinės pedagogikos studiju programu studentams ugdytis vadybines kompetencijas, pasirinktas kvazieksperimentinis tyrimas, kuriame dalyvavo 4 aukštosios mokyklos ( 2 universitetai ir 2 kolegijos), iš kurių sudarytos 2 eksperimentinès (40 studentu) ir 2 kontrolinės (40 studentu) grupès. Aukštosios mokyklos kvazieksperimentui pasirinktos netikimybiniu patogiuoju būdu (laikantis teritorinio principo). Tiriamuju grupių parinkimo būdas - puokštès, arba serijinis. Pasirinktos aukštosios mokyklos, kurios sutiko bendradarbiauti atliekant kvazieksperimentini tyrima, jose tirti visi pagal socialinès pedagogikos studijų programas (nuolatiné forma) studijuojantys antro ir trečio kurso studentai. Iš viso tyrime dalyvavo 80 socialinės pedagogikos studijų programų studentų: 52,5\% studijavo universitete, 47,5\% - kolegijoje: iš jų 73,8 \% studijavo trečiame kurse, $26,2 \%$ - antrame kurse. Respondentų amžius pasiskirstė tarp 18 ir 40 metų, didžioji dalis respondentų buvo nuo 20 iki 22 metų (amžiaus vidurkis -21,47 metu), 97,5\% - moterys, 2,5\% - vyrai. Sudarant eksperimentines ir kontrolines grupes laikytasi homogeniškumo principo, grupès parinktos taip, 
kad jų parametrai būtų kuo panašesni, t. y. būtų panašaus dydžio, ta pati studijų forma, panašaus amžiaus, lyties ir pan. Prieš pradedant kvazieksperimentini tyrimą, gautas aukštujų mokyklų vadovų leidimas vykdyti tyrimą ir kiekvieno dalyvio sutikimas žodžiu dalyvauti tyrime.

Kvazieksperimentinis tyrimas organizuotas etapais: 1) studentų apklausa raštu (pre-test) iki eksperimentinès intervencijos; 2) eksperimentinė intervencija (testfactor), tobulinant studentų savarankišką darbą; 3) studentų apklausa raštu (posttest) po eksperimentinès intervencijos.

Kvazieksperimento intervencijos metu, remiantis konstruktyvistinès teorijos idejomis, tobulintas studentų savarankiškas darbas pagal tyrèjos parengtą savarankiško darbo tobulinimo metodiką (test-factor). Studentų savarankiškam darbui parinktos taikomojo pobūdžio užduotys, taikomi konstruktyvia ir aktyvia studentu veikla grindžiami studijų metodai, tokie kaip darbas grupėse, atvejų analizé, projektinè, tiriamoji veikla ir pan. Savarankiško darbo vertinimas tobulintas, itraukiant vertinimą užduočių atlikimo procese, parenkant ir taikant atliktos veiklos demonstravimu grindžiamus kompetencijų vertinimo metodus bei teikiant grižtamaji ryši Užduočių vertinimo kriterijai sieti su vadybinèmis kompetencijomis ir atliekamos veiklos rezultatų kokybės vertinimu. Vertinant savarankišką darbą studentams buvo sudaromos sąlygos patiems issivertinti ir įvertinti igyjamas kompetencijas.

Intervencijos planavimo pakopoje surašytas veiksmų planas kiekvienam savarankiško darbo struktūriniam elementui tobulinti, t. y. kokius veiksmus reikia atlikti siekiant patobulinti savarankiško darbo procesą studentų vadybinių kompetencijų ugdymui/si. Parengta savarankiško darbo metodika taikyta per studiju dalykus, kuriu dèstytojai sutiko dalyvauti tyrime. Atliekant kvazieksperimenta, laikytasi šių tyrimo procedūrų: dėstytojai prieš eksperimentą instruktuoti, pateikiant metodinès idejjos igyvendinimo, metodinių didaktinių priemonių (savarankiško darbo aprašo, savarankiško darbo užduočių vertinimo kriterijų, studentams isivertinti skirtų metodinių priemonių) pavyzdžius.

Šio tyrimo instrumento pagrindą sudare atskleista socialinio pedagogo vadybiniu kompetencijų struktūra. Vadybines skales sudarantys kintamieji grupuoti pateikiant juos atskirais klausimais pagal socialinio pedagogo veiklos lygmenis: individualaus darbo su vaiku, mokinių grupėmis, vaikų / mokinių tėvais ir jų grupėmis, mokyklos bendruomene (administracija, mokytojais, klasių auklètojais ir kitais specialistais), tarpinstituciniu lygmeniu.

Vadybines skales sudarantys teiginiai, apibūdinantys socialinio pedagogo darbui mokykloje svarbias vadybines kompetencijas, vertinti pagal šešių balų rangų sistema, kurioje 1 balas reiškia, kad neigijo atitinkamos kompetencijos, 6 balai kad igijo labai aukštą kompetenciją ( 1 - žemiausias balas, 6 - aukščiausias balas). Vertinant vadybinių kompetencijų skalès ir pavienių subskalių pagal socialinio 
pedagogo veiklos lygmenis patikimumą taikyta patikimumo analizè (angl. Reliability analysis); gauta vadybinių kompetencijų skalès Cronbach's alpha - 0,992; konkrečių subskalių - nuo 0,942 (individualus darbas su vaiku) iki 0,986 (darbas su vietos bendruomene ir kitomis institucijomis). Kiekviename socialinio pedagogo veiklos lygmenyje skalę sudarantys kintamieji sugrupuoti ir i pavienius planavimo, organizavimo, vadovavimo ir kontrolès kompetencijų kintamuosius. Vertinant minètų pavienių subskalių patikimumą nustatyta Cronbach's alpha-nuo 0,692 iki 0,971. Šie duomenys leidžia teigti, kad kompetencijų subskalès yra patikimos matavimo priemonès.

Kvazieksperimentinis tyrimas truko vienerius mokslo metus. Duomenys buvo renkami dviem momentiniais pjūviais (prieš ir po eksperimento), t. y. mokslo metų pradžioje ir mokslo metų pabaigoje. Palyginus rezultatų pre-test ir post-test skirtumus, įvertintas savarankiško darbo, grindžiamo konstruktyvistinės teorijos idejjomis, poveikis socialinès pedagogikos studiju programų studentų vadybiniu kompetencijų ugdymui/si. Apklausos raštu testavimo-retestavimo metu surinkti duomenys apdoroti taikant vienfaktorinès dispersinès analizès (anova) su Post hoc kriterijumi (Tukey HSD) statistini metodą. Populiacijos kintamujų dispersijų lygybé tikrinta, naudojant Levene testą, kurio rezultatai $(p>0,05)$ parodé, kad populiacijos dispersijos yra homogeniškos ir galima daryti tolesnes statistines išvadas.

\section{Tyrimo rezultatai}

Siekiant atskleisti kvazieksperimento intervencijos poveiki socialinès pedagogikos studijų programų studentų vadybinių kompetencijų ugdymui/si, eksperimentinėse grupėse lyginti vadybinių kompetencijų subskalių įsivertinimo rodikliai prieš (pre-test) ir po eksperimento (post-test) (̌̌r. 1 lentelę).

1 lentele. Vadybinių kompetencijų ịsivertinimas eksperimentinėse grupėse prieš kvazieksperimento intervenciją ir po jos Table 1. Self-assessment of management competencies in experimental groups before the intervention of quasi-experiment and after it

\begin{tabular}{|l|c|c|c|c|c|c|}
\hline Vadybinių kompetencijų subskalès & E1 & E2 & $\begin{array}{c}\text { Vidurkių } \\
\text { skirtumai }\end{array}$ & $F$ & $d f$ & $p$ \\
\hline Planavimas & 3,70 & 4,04 & 0,34 & 2,388 & 3 & 0,151 \\
\hline Organizavimas & 3,36 & 3,94 & $\mathbf{0 , 5 8}$ & $\mathbf{5 , 2 2 3}$ & $\mathbf{3}$ & $\mathbf{0 , 0 2 6}$ \\
\hline Vadovavimas & 3,47 & 3,86 & 0,39 & 3,213 & 3 & 0,224 \\
\hline Kontrolé & 3,66 & 4,11 & 0,45 & 3,694 & 3 & 0,079 \\
\hline
\end{tabular}

Pastaba. E1-eksperimentinès grupès prieš kvazieksperimento intervencija; E2 - eksperimentinès grupès po kvazieksperimento intervencijos. 
Analizuojant eksperimentinių grupių studentų vadybinių kompetencijų subskalių isivertinimo rodiklius prieš ir po kvazieksperimento intervencijos, nustatyta, kad po eksperimento reikšmingai gerejo $(p=0,026)$ eksperimentinių grupių studentų organizavimo kompetenciju subskalès įsivertinimo rodiklis. Statistiškai reikšmingų skirtumų nenustatyta $(p>0,05)$ planavimo, vadovavimo ir kontrolès kompetencijų subskalèse (žr. 1 lentelę).

Kvazieksperimento intervencijos poveikis eksperimentiniu grupiu studentu vadybinių kompetencijų ugdymui/si tikrintas, analizuojant studentų vadybinių kompetenciju issivertinimo rodiklius pagal socialinio pedagogo veiklos lygmenis. Kaip ir tiketasi, patobulinus savarankiško darbo struktūrinius elementus, po taikytos intervencijos eksperimentiniu grupių studentai vadybines kompetencijas įsivertino geriau nei prieš kvazieksperimento intervenciją (žr. 2 lentelę).

2 lentelè. Vadybinių kompetencijų įsivertinimas eksperimentinèse grupèse prieš kvazieksperimento intervenciją ir po jos

Table 2. Self-assessment of management competencies in experimental groups before the intervention of quasi-experiment and after it

\begin{tabular}{|l|c|c|c|c|c|c|}
\hline \multicolumn{1}{|c|}{ Veiklos lygmenys } & E1 & E2 & $\begin{array}{c}\text { Vidurkių } \\
\text { skirtumai }\end{array}$ & $F$ & $d f$ & $p$ \\
\hline Individualus darbas su vaiku & 3,90 & 4,21 & 0,31 & 1,182 & 3 & 0,248 \\
\hline Darbas su mokiniu grupemis & 3,73 & 4,19 & $\mathbf{0 , 4 6}$ & $\mathbf{3 , 0 6 9}$ & $\mathbf{3}$ & $\mathbf{0 , 0 3 7}$ \\
\hline $\begin{array}{l}\text { Darbas su mokiniu tevais ir ju } \\
\text { grupemis }\end{array}$ & 3,62 & 3,89 & 0,27 & 2,614 & 3 & 0,595 \\
\hline $\begin{array}{l}\text { Darbas su mokyklos } \\
\text { bendruomene }\end{array}$ & 3,49 & 3,97 & 0,48 & 3,906 & 3 & 0,117 \\
\hline $\begin{array}{l}\text { Darbas su vietos bendruomene ir } \\
\text { kitomis institucijomis }\end{array}$ & 3,09 & 3,71 & $\mathbf{0 , 6 2}$ & $\mathbf{5 , 9 2 0}$ & $\mathbf{3}$ & $\mathbf{0 , 0 4 0}$ \\
\hline
\end{tabular}

Pastaba: E1-eksperimentinés grupès prieš kvazieksperimento intervencija; E2 - eksperimentinés grupés po kvazieksperimento intervencijos.

Tyrimo rezultatai parode, kad po kvazieksperimento intervencijos eksperimentinèse studentų grupėse reikšmingai gerẻjo vadybinių kompetencijų isivertinimo rodikliai darbui su mokiniu grupèmis ( $p=0,037)$, vietos bendruomene ir kitomis institucijomis $(p=0,040)$ lygmenyse. Analizuojant eksperimentiniu grupių studentų vadybinių kompetencijų issivertinimo rodiklius individualaus darbo su vaiku, mokiniu tévais ir ju grupèmis, mokyklos bendruomene lygmenyse matyti, kad po taikytos intervencijos eksperimentiniu grupių studentai vadybines kompetencijas įsivertino geriau nei prieš kvazieksperimento intervenciją, tačiau statistiškai reikšmingų skirtumų nenustatyta $(p>0,05)$ (žr. 2 lentelę). 
3 lentele. Vadybinių kompetencijų socialinio pedagogo darbui su vietos bendruomene ir kitomis institucijomis ịsivertinimas eksperimentinèje grupeje prieš kvazieksperimento intervenciją ir po jos

Table 3. Self-assessment of management competencies for work of a social care educator with local community and other institutions in experimental group before the intervention of quasi-experiment and after it

\begin{tabular}{|l|c|c|c|c|c|c|}
\hline $\begin{array}{c}\text { Vadybinių kompetencijų } \\
\text { subskalès }\end{array}$ & $\mathrm{E} 1$ & $\mathrm{E} 2$ & $\begin{array}{c}\text { Vidurkių } \\
\text { skirtumai }\end{array}$ & $F$ & $d f$ & $p$ \\
\hline Planavimas & 3,17 & 3,86 & $\mathbf{0 , 6 9}$ & 4,625 & 3 & $\mathbf{0 , 0 1 9}$ \\
\hline Organizavimas & 3,01 & 3,73 & $\mathbf{0 , 7 2}$ & $\mathbf{5 , 7 1 6}$ & $\mathbf{3}$ & $\mathbf{0 , 0 2 2}$ \\
\hline Vadovavimas & 3,08 & 3,66 & 0,58 & 6,294 & 3 & 0,074 \\
\hline Kontrolė & 3,31 & 3,88 & $\mathbf{0 , 5 7}$ & 4,160 & 3 & $\mathbf{0 , 0 4 4}$ \\
\hline
\end{tabular}

Pastaba: E1 - eksperimentinès grupès prieš kvazieksperimento intervencija; E2 - eksperimentinès grupès po kvazieksperimento intervencijos.

Analizuojant eksperimentinių grupių studentų isivertinimo rodiklius vadybiniu planavimo, organizavimo, vadovavimo, kontrolès kompetencijų tarpinstituciniame lygmenyje, nustatyta, kad po taikytos kvazieksperimento intervencijos reikšmingai gerejo studentu planavimo $(p=0,019)$, organizavimo $(p=0,022)$ ir kontrolés $(\mathrm{p}=0,044)$ kompetencijų darbui su vietos bendruomene ir kitomis institucijomis lygmenyje subskalių i̇sivertinimo rodikliai. Statistiškai reikšmingų skirtumų nenustatyta tik vadovavimo kompetenciju ( $p>0,05)$ subskaleje (žr. 3 lentelę).

\section{Diskusija}

Šio kvazieksperimentinio tyrimo tikslas - atskleisti konstruktyvistinėmis idèjomis grindžiamo savarankiško darbo įtaką socialinès pedagogikos studijų programų studentų vadybinių kompetencijų ugdymui/si. Kvazieksperimento intervencijos metu socialinès pedagogikos studiju programu studentu savarankiško darbo tobulinimas sietas su konstruktyvistinès teorijos taikymu. Tyrimo rezultatai patvirtino, kad konstruktyvistinės teorijos idejomis grindžiamas savarankiškas darbas padeda socialinès pedagogikos studijų programų studentams ugdytis vadybines kompetencijas. Konstruktyvistinès teorijos požiūriu, mokymasis suprantamas kaip procesas, kuriame besimokantysis, aktyviai dalyvaudamas, taikydamas žinias praktineje veikloje, vertindamas jų naudą, igytos patirties pagrindu tobulina kompetencijas (Pečiūrienè ir kt., 2010; Šliogerienè, Liuolienè, Metiūnienė, 2009; Valuckienè, 2009). Konstruktyvistinèmis idèjomis grindžiamo savarankiško darbo esmè - paties individo konstruktyvi veikla, sudarant jam tinkamas mokymosi sąlygas ir suteikiant parama, kurios reikia, siekiant užtikrinti mokymosi veiklą. Šio tyrimo duomenys sutampa su kitų autoriu (Pečiūrienė ir kt., 2010; Šliogerienè ir 
kt., 2009; Valuckienė, 2009; Šiaučiukėnienė ir kt., 2006; Brunevičiūtė ir kt., 2003) darbais, kurie parodo, kad, sudarant sąlygas aktyviai veikti, taikyti žinias praktinejje veikloje, vertinti jų naudą, sudaromos sąlygos studentams patiems ugdytis profesinei veiklai būtinas kompetencijas.

Kaip ir tikètasi, kvazieksperimento intervencijos metu patobulinus savarankišką darbą, gerejo eksperimentinių grupių studentų vadybinių kompetenciju ịsivertinimo rodikliai visuose socialinio pedagogo veiklos lygmenyse. Tyrimo rezultatai parodè, kad kvazieksperimento metu, taikant tyrëjos parengtą savarankiško darbo tobulinimo metodiką, reikšmingai gerejjo studentų vadybinių kompetencijų, būtinu socialinio pedagogo darbui su mokinių grupèmis ir tarpinstituciniame lygmenyse, issivertinimo rodikliai. Tai pagrindžia tyrimo rezultatu aktualumą mokyklos socialinio pedagogo praktinei veiklai. Remiantis pastaraisiais metais atliktu tyrimu (Buzaitytė-Kašalynienė, 2003; Švedaitè, 2005; Indrašienė ir kt., 2008; Leliūgienė ir kt., 2008) rezultatais, daugeliui socialinių pedagogų trūksta vadybinių kompetencijų tarpinstituciniame lygmeyje, kai socialinè pedagoginè pagalba teikiama per organizacijas ar institucijas, kurios sudaro socialinès pagalbos sistemą. Mokslininkai (Švedaitė, 2005; Buzaitytè-Kašalynienè, 2003) pažymi, kad šiandieninėje praktikoje organizacinis aspektas, kai pagalba teikiama tik per organizacijas ar institucijas, tampa viena esminių vadybinès veiklos funkcijų. Tyrimo rezultatai parodè, kad konstruktyvistinès teorijos idejjomis grindžiamas savarankiškas darbas padeda socialinès pedagogikos studijų programų studentams ugdytis socialinio pedagogo darbui būtinas vadybines kompetencijas sisteminiame lygmenyje, t. y. darbui organizacijos ir jos aplinkos lygmenyse.

Remiantis mokslininkų (Leliūgienè ir kt., 2008; Indrašienè ir kt., 2008; Kvieskienè ir kt., 2006) atliktų tyrimų rezultatais, socialiniam pedagogui būtina ugdytis planavimo, organizavimo, vadovavimo, kontrolès gebëjimus. Reikšmingas šio tyrimo aspektas, kad po taikytos kvazieksperimento intervencijos reikšmingai gerejjo issivertinimo rodikliai eksperimentinès grupès studentu planavimo, organizavimo, kontrolès kompetencijų darbui su vietos bendruomene ir kitomis institucijomis lygmenyje.

Kvazieksperimentinis tyrimas kai kuriais aspektais buvo ribotas. Pirmiausia pabrěžtina, kad reikšmingai keitèsi ne visi analizuojami kintamieji. Pavyzdžiui, reikšmingai nepakito studentų vadybinių kompetencijų įsivertinimo rodikliai individualaus darbo su vaiku, vaikų / mokinių tėvais ir jų grupėmis, mokyklos bendruomenès lygmenyse. Reikšmingai nesikeite ir eksperimentinès grupès studentu isivertinimo rodikliai vadovavimo kompetencijų darbui su vietos bendruomene ir kitomis institucijomis lygmenyje. Atliekant tolesnius tyrimus galima būtų aiškintis, kokie savarankiško darbo struktūriniai elementai turi įtakos socialinès pedagogikos studijų programų studentų vadovavimo kompetencijų ugdymui/si. 
Reikètu paminèti, kad esant gana mažam atvejų skaičiui aukštosiose mokyklose, sudarant tyrimo imti tiriamuju grupès formuotos iš antro ir trečio kursų studentŭ, kas apsunkino kvazieksperimentinès intervencijos valdymą. Be to, reikètu paminèti, kad savarankiškas darbas tobulintas per studijų dalykus, kurių dėstytojai sutiko dalyvauti tyrime. Savarankiškam darbui aukštojoje mokykloje tobulinti svarbu, kad socialinès pedagogikos studijų programos visų studijų dalykų savarankiškas darbas būtų grindžiamas tomis pačiomis kvazieksperimentinèmis idèjomis. Svarbu, kad aukštojoje mokykloje būtų laikomasi vieningos edukacinès paradigmos, dèl kurios sutartų visi studijų veikèjai (studijų programos rengèjai, dėstytojai ir studentai) (Pečiūrienè ir kt., 2010; Le Boterf, 2009; Jucevičienė, Valuckienė, 2008; Nieto ir kt., 2008; Broad, 2006; Šiaučiukenienè ir kt., 2006). Remiantis šio kvazieksperimentinio tyrimo rezultatais gali būti tobulinamas socialinès pedagogikos programų studentų savarankiškas darbas aukštosiose mokyklose.

\section{Išvados}

Kvazieksperimentinis tyrimas patvirtino, kad konstruktyvistinès teorijos idejomis grindžiamas studentų savarankiškas darbas padeda ugdytis socialinio pedagogo darbui svarbias vadybines kompetencijas.

Kvazieksperimento intervencijos metu, patobulinus studentu savarankišką darba, reikšmingai gerẻjo studentų vadybinių kompetencijų įsivertinimo rodikliai socialinio pedagogo darbui su mokinių grupèmis, vietos bendruomene ir kitomis institucijomis lygmenyse.

Vertinant vadybines socialinio pedagogo darbo su vietos bendruomene ir kitomis institucijomis kompetencijas reikšmingai gerèjo planavimo, organizavimo, kontrolès kompetencijų įsivertinimo rodikliai.

Konstruktyvistinès teorijos idėjomis grindžiamas studentų savarankiškas darbas padeda studentams ugdytis vadybines kompetencijas socialinio pedagogo darbui sisteminiame lygmenyje, t. y. teikti organizuot $q$ socialine pagalb $q$ per organizacijas ar institucijas, kurios sudaro socialinès pagalbos sistemą.

Gauta 20130912

Pasirašyta spaudai 20140214

\section{Literatūra}

Broad, J. (2006). Interpretations of independent learning in further education. Journal of Further and Higher Education, vol. 30 (2): 119-143.

Brunevičiūtė, R., Gudaitytė, D., Starkutè, D., Šarkauskienė, L. (2003). Mokymosi priemonių, igalinančių studentų savarankišką darbą, rengimas. Aukštojo ir vidurinio mokslo sanglauda: ugdymo turinio ir didaktikos tradicijos ir kaita. IX tarptautiné mokslinè konferencija. Mokslo darbai. Vilnius, p. 18-24. 


\section{Asta Mažionienè}

Buzaitytè-Kašalynienè, J. (2003). Socialinio pedagogo veikla bendrojo lavinimo mokykloje. Acta paedagogica Vilnensia. Mokslo darbai, vol. 10, p. 29-47. Vilnius: Vilniaus universiteto leidykla.

Dačiulytė, R. (2003). Studentų savarankiškumo sampratos bruožai. Aukštojo ir vidurinio mokslo sanglauda: ugdymo turinio ir didaktikos tradicijos ir kaita. IX tarptautinè mokslinè konferencija. Mokslo darbai. Vilnius, p. 33-40.

Dillon, C., Greene, B., Mansell, R. (2005). Assesing Approaches to Learning in Independent Learning Environments in Higher Education. Prieiga internete: http://www.formatex.org/micte [žiūrèta 2012-09-10].

Hendry, G. D., Hyde, S. J., Davy, P. (2005). Independent student study groups. Medical Education, vol. 39: 672-679.

Indrašienė, V., Merfeldaitè, O., Petronienė, O. (2008). Šiuolaikiniu vadybiniu funkciju taikymas organizuojant mokyklos veikla. Mokslinio tyrimo ataskaita. Vilnius: Lietuvos socialiniu pedagogų asociacija.

Jucevičienè, P., Valuckienè, J. (2008). Conventionality of the Quality of Studies: Context of the Expression of Educational Paradigm. Social Sciences, vol. 4 (62): 37-50.

Kvieskienė, G., Indrašienė, V., Merfeldaitè, O. (2006). Socialinès pedagoginès pagalbos komandos narių atrankos kriterijai. Pedagogika. Mokslo darbai, nr. 83: 103-107.

Kvieskiené, G. (2001). Socialinio pedagogo kompetencijos samprata. Pedagogika. Mokslo darbai, nr. 53: 63-69.

Le Boterf, G. (2009). Universitetinių studiju programos kūrimas: kompetencijų prieigos ir proceso samprata. Tiltai/Bridges, nr. 1 (46): 135-141.

Leliūgienė, I., Baršauskiené, V., Mertinkaitytė, E. (2008). Socialinio pedagogo vadybinè veikla. Socialinis darbas. Mokslo darbai, nr. 7(3): 129-139. Vilnius: Mykolo Romerio universitetas.

Majauskienė, L., Leliūgienė, I. (2008). Differentation Levels of School Social Pedagogue Activity: Theoretical and Empirical Insights in the Context of Lithuania and Germany. Social Sciences/ Socialiniai mokslai, nr. 3 (61): 60-69. Kaunas: Technologija.

Mažionienė, A., Rupšienè, L. (2011). Studentu vadybinės kompetencijos, igytos studijuojant pagal socialinès pedagogikos studiju programas. Tiltai/Bridges, nr. 2 (55): 125-137.

Nieto, F., Dimitriadou, A., Davy, N. (2008). Developing Skills for Independent Learning for Access to Higher Education Students. FACE Conference, St John University, York.

Pečiūrienė, A., Radlinskaitė, R., Žvinakevičienė, D. (2010). Savarankiškas darbas profesinio bakalauro studiju procese. Prieiga internete: www.viko.lt [žiürèta 2012-09-10].

Rupšienė, L., Mažioniené, A. (2011). Savarankiškas darbas aukštojoje mokykloje socialinio pedagogo vadybinių kompetencijų ugdymo požiūriu: studentų nuomonè. Tiltai/Bridges, nr. 3 (56): 151-158.

Seilius, A. (1998). Organizaciju tobulinimo vadyba. Monografija. Klaipèda: Klaipedos universiteto leidykla.

Socialinio pedagogo kvalifikaciniai reikalavimai. (2001). Lietuvos Respublikos Švietimo ir mokslo ministro 2010-12-14 isakymas Nr. 1667 „Dèl socialinio pedagogo kvalifikacinių reikalavimų ir pareiginių instrukcijų patvirtinimo“. Valstybès žinios, 2002, nr. 24-896.

Socialinio pedagogo pareiginè instrukcija. (2001). Lietuvos Respublikos švietimo ir mokslo ministro 2010-12-14 isakymas nr. 1667 „Dèl socialinio pedagogo kvalifikacinių reikalavimų ir pareiginių instrukcijų patvirtinimo“. Valstybés žinios, 2002, nr. 24-896.

Socialinio pedagogo rengimo standartas. (2008). Vilnius: Profesinio mokymo metodikos centras. Lietuvos Respublikos Švietimo ir mokslo ministro ir Lietuvos Respublikos Socialinės apsaugos ir darbo ministro 2008-06-26 isakymas Nr. ISAK-1872/A1-209.

Stankevičiené, A., Lobanova, L. (2006). Personalo vadyba organizacijos sistemoje. Vilnius: Technika.

Stoner, J., Freeman, R., Gilbert, D. (2005). Vadyba. Kaunas: Poligrafija ir informatika.

Šiaučiukèniené, L., Visockienė, O., Talijūnienè, P. (2006). Šiuolaikinès didaktikos pagrindai. Kaunas: Technologija.

Šliogerienė, J., Liuolienė, A., Metiūnienė, R. (2009). Studento savarankiškos veiklos ugdymo kryptys. Santalka. Filologija. Edukologija, t. 17 (2): 81-87.

Švedaitè, B. (2005). Sèkmingos socialinès pedagoginès veiklos veiksniai: empirinès išvados. Acta paedagogica Vilnensia. Mokslo darbai, nr. 14: 133-144.

Tandzegolskienè, I., Pileckaite, R. (2010). Socialinių mokslų srities studentų savarankiškos veiklos raiška universitetinèse studijose. Pedagogika, nr. 97: 43-49.

Valuckienė, J. (2009). Mokymosi paradigma gristos studijos kaip atsakas į besikeičiančios visuomenès lūkesčius universitetinèms studijoms. Ekonomika ir vadyba: aktualijos ir perspektyvos, nr. 2 (15): 311-317.

Zakarevičius, P. (2002). Vadyba: genezè, dabartis, tendencijos. Monografija. Kaunas.

Želvys, R. (2001). Švietimo vadybos pagrindai. Vilnius: Vilniaus universiteto leidykla.

Želvys, R. (2003). Švietimo organizaciju vadyba. Vilnius: Vilniaus universiteto leidykla. 


\section{THE INFLUENCE OF INDIVIDUAL WORK ON THE EDUCATION/ SELF-EDUCATION OF MANAGEMENT COMPETENCIES OF STUDENTS OF SOCIAL PEDAGOGY STUDY PROGRAMMES}

\section{Asta Mažionienè}

Summary

Research done in recent years shows that the majority of social care educators lack management competencies, particularly organized help, i.e. at systematic level when social pedagogical help is provided through organizations and institutions that form the system of social support, whereas a social care educator becomes the leader of this system and the process. Consequently, it is relevant to search for ways how to help students of social pedagogy programmes at higher school to educate management competencies. Management competencies involve knowledge, abilities and provisions necessary for the fulfillment of managing functions: planning, organization, leadership, and control. Social care educators in their activity have to plan work, make decisions, organize, conscript, control, and lead the process of children's social education. In the article individual work has been analyzed as the significant factor for the education of management competencies of social care educators. Following the contemporary paradigm of learning, it is necessary that student's individual work at higher school would constitute the background for the education of student competencies. That's why, in contemporary studies of higher education individual work should be based on the new learning paradigm and constructivism theory suggesting that learning is the process in which a learner through active participation, application of knowledge in practical activity, evaluating their advantage on the basis of experience gained improves abilities, develops knowledge and skills. From the point of view of constructivism theory, competencies are constructed through the social participation of individuals in activity by solving problems as well as accomplishing tasks. While individual work at higher school based on constructionism ideas has been chosen as the object of the research, the aim raised in this article is to reveal the impact of individual work based on constructivism ideas on the education/self-education of management competencies of students of social pedagogy studies programmes.

With the aim to prove that individual work based on conctructionism ideas at higher school helps students to educate management competencies, the quasiexperimental research has been implemented. 4 higher schools ( 2 universities and 2 colleges) have participated in the research. 2 experimental (40 students) and 2 control (40 students) have been formed. The choice of researched groups: bunch 
or serial. Higher schools that agreed to cooperate have been chosen for the implementation of quasi-experimental research where all first and second year students of social pedagogy study programmes studying full-time have been analyzed. In total, 80 students of social pedagogy studies programmes participated in the research. By forming experimental and control groups it was stuck to the principle of homogeneity; groups were chosen in the way that parameters would be as similar as possible, i.e. they would be of similar size, students would study in the same mode, would be of similar age, sex, and so on. Quasi-experimental research was organized in separate stages: the survey of students (pre-test) before experimental intervention; experimental intervention (test-factor) by improving individual work of students; the survey of students (post-test) after experimental intervention. The duration of quasi-experimental research: one academic year. Data was collected through two instantaneous cuts (before and after experiment), i.e. in the beginning of academic year and at the end of academic year. After the comparison of differences between pre-test and post-test, the impact of individual work based on constructivism ideas on the education/self-education of management competencies of students of social pedagogy studies programmes. The data collected during the testing - retesting of written survey by application of the statistical method of one-factor dispersion analysis (anova) with Post hoc criterion (Tukey HSD) was applied.

During the quasi-experimental intervention, with reference to constructivism ideas, individual work of students was improved according to the improvement methodology (test-factor) arranged by the researcher. Tasks of applied character were chosen for individual work of students, studies methods based on constructive and active student activity were chosen, such as work in groups, case analysis, project and research activity and so on. Evaluation of individual work was improved by including the assessment in the process of tasks accomplishment by choosing and applying reversible connection. Criteria for task evaluation were related to management competencies and evaluation of the quality of results of accomplished activity. During individual work evaluation students were provided with circumstances to evaluate themselves and competencies acquired.

The basis of this research instrument is formed of the structure of management competencies of a social care educator. Variables forming the management scale were grouped by presenting them in different questions according to the levels of activity of a social care teacher: individual work with a child, student groups, children/students parents and their groups, at school and interinstitutional levels. As it was expected, by improvement of individual work during the quasi-experimental intervention the self-assessment indicators of management competencies of students from experimental groups at all activity levels of a social care educator 
improved. Research findings have shown that during the quasi-experiment by applying the methodology of improvement of individual work arranged by the researcher, self-assessment indicators of management competencies of students for the work of a social care educator with student groups and at interinstitutional level. This substantiates the relevance of research results to practical activity of a social care educator. Significant aspect of this research is that results of it have shown that individual work based on the ideas of constructivism theories helps students of social pedagogy studies programmes to educate management competencies for the work of social care educator at the systematic level, i.e. to the work at the levels of organization and its environment. The significant aspect of this research is that after the quasi-experimental interventions applied the self-assessment indicators of planning, organization, control competencies of students from experimental groups for the work at the levels of local community and other institutions have improved.

Individual work of students of social pedagogy studies programmes at higher schools may be improved by means of the results of quasi-experimental research. 
